\title{
Prospects and Challenges of Inclusion of Children with Disabilities into Regular School Setting in Nigeria
}

\author{
Dr. Dorcas Oluremi FAREO* \\ Department of Educational Foundations, Faculty of Education, Adamawa State University, Mubi, Nigeria
}

DOI: $\underline{10.36348 / \mathrm{sjhss} .2020 . \mathrm{v} 05 \mathrm{i} 06.001}$

| Received: 30.05 .2020 | Accepted: 08.06.2020 | Published: 11.06 .2020

*Corresponding author: Dr. Dorcas Oluremi FAREO

\section{Abstract}

Inclusion is a programme that caters for the education of individuals with disabilities in a regular school setting. This paper takes a cursory look at concepts of inclusive education, inclusive education policy in Nigeria, learning theories of inclusion such as Social Learning Theory by Bandura, Observation Learning Theory by Piaget and Vygotsky and Guided Learning Theory by Vygotsky are critically examined. Inclusion has academic and social benefits for all students, whether with or without disabilities, such as increased communication and social interaction opportunities, ageappropriate models of behaviour skills, active participation in the school community, individualized education goals, as well as access to rich core curriculum. The challenges of inclusive education are in the areas of funding, inadequate personnel, facilities and materials; lack of communication among administrators, teachers, specialists, staff, parents and students inhibits the success of inclusive programme. Counselling the public for attitudinal change would accommodate the students with special needs in our society, but; would also make them to be accepted as people of worth. It is recommended to all school system to initiate seminars, workshops and conferences for parents of students with special needs; so that awareness could be brought about on needs of families. The curriculum should be modified to accommodate learners with special needs different learning style so as to achieve the needed change.

Keywords: Inclusive education, students with special needs, children with disabilities, special Teachers and inclusive educational policy.

Copyright @ 2020: This is an open-access article distributed under the terms of the Creative Commons Attribution license which permits unrestricted use, distribution, and reproduction in any medium for non-commercial use (NonCommercial, or CC-BY-NC) provided the original author and source are credited.

\section{CONCEPT OF INCLUSION}

Stevens [1] considers an inclusive classroom as a replacement option for students with learning disabilities. The author explains further, that, it is a least restrictive form of education for special needs students and it allows the students to be included in a typical classroom enrolment with his or her peers. Inclusive education is concerned with minimizing and removing barriers to access, participation and learning for all children, but especially for those who have been socially discriminated because of poverty, disability, gender, religion, ethnicity or any inequalities [2].

Centre for Studies on Inclusive Education [3] as cited in Okobah [4] and Omede [5] defines inclusive education as a programme for all children and young people with or without disabilities or difficulties learning together in ordinary pre-primary provisions, schools, colleges and universities with appropriate network. Kochlar, West and Taman [6] equally stated that inclusion in special education means that schools, classes and activities are scheduled for students with disabilities so that opportunities for their participation are maximized. UNESCO [7], perceives it as a process of transforming schools and other centers of learning to linguistic minorities, rural populations, those infected and affected by HIV and AIDS, those with disabilities and difficulties in learning and as well provide learning opportunities for all. Accommodating such learners will in small way help in developing self-esteem needed to overcome obstacle that the disability would have posed to them.

\section{Inclusive Education Policy in Nigeria}

According to Federal Government of Nigeria [8], a programme known as "Special Education" was designed to cater for three categories of individuals thus:

1) The Disabled including people with physical, visual, hearing, mental, emotional, social, speech, learning and multiple impairments. 2) The Disadvantaged involving the children of nomadic 
pastorals, migrant fisher folks, migrant farmers and hunters 3) The Gifted and Talented involving people (Children and Adults) who have high intelligent quotient and endowed with special traits in arts, creativity, music, leadership, intellectual precocity and therefore find themselves insufficiently challenged by the regular schools.

Furthermore by the provision of the policy, educations of children with special needs are expected to be free at all levels and all necessary facilities that would ensure easy access to education shall be provided to include: a) Inclusive education or integration of special classes and units into ordinary/public schools under the Universal Basic Education (UBE) scheme; b) Regular census and monitoring of people with special needs to ensure adequate educational planning and welfare programme; (c) Special education equipment and materials like Perkins Braille, white/mobility care, brailed textbooks, abacus, talking watch, audiometers, speech trainers, hearing aids, ear molding machines, educational toys, calipers, crutches, wheel chairs, artificial limbs, audio-visual equipment and internet facilities; (d) Special education training on Braille reading and writing, typewriter use, speech signs, daily living skills; (e) Special training and re-training of the personnel on capacity building to keep them abreast of latest teaching techniques on various categories of disabilities, the gifted and talented; and (f) A teacherpupil ratio of $1: 10$ in special schools. Equally the special schools are to arrange for effective architectural designs of school buildings with regular sensory, medical and psychological screening assessments to identify any incidence of handicap.

Special education provides the best platform to attend to the needs of these persons. The goal of special education is to equalize for its clients available opportunities in the society. It operates on the philosophy of 'catch them young', that is why it starts as soon as a child is detected to have special needs and it pursues this mandate through the early intervention programme. Some vital areas of special education services include vocational, community based and medical rehabilitation, assessment/identification strategies, home/hospital based services, provision of materials/equipment and assistive technology for persons with disabilities, special education teachers/para-professionals. These services are provided as integral aspects of special education programme geared towards securing an independent and self-reliant existence for persons with disabilities $[9,10]$.

\section{Learning Theories on Inclusion}

\section{(a) Social Learning Theory}

Albert Bandura developed the social learning theory which states that learning, both cognitive and behavioral, takes place through the observation, modeling, and imitation of others. The main characteristic of the social learning theory, are the centrality of observational learning, a Causal model that involves an environment- person- behavior system, cognitive contributions, and Self-efficacy and agency [11]. This theory proposes that academic and behavior. Modelling takes place through verbal instruction, live modeling by a person, and symbolic model ing through four steps: attention, retention, reproduction, and motivation. Inclusion classes capitalize on this theory because disabled peers can observe their nondisabled peers and their teachers and then imitate them both academically and behaviorally. Advocates for inclusion thought this course of action would help students with disabilities by emerging them into a learning community that mimics a mini society. Through this learning community students with disabilities are able to interact with their peers and develop friendships. When included in the regular classroom, special needs students have the opportunity to see their peers working habits, and they can model those habits and behaviors to reflect their own.

\section{(b) Observational Learning Theory}

Students with special needs can learn not only desired behaviours from their peers through social interaction, they can also learn academically within their learning community. Children can be the best teachers. Cooperative learning involves social interaction amongst the students, and it is the key to educational thinkers such as Piaget and Vygotsky [1]. Using social interaction and active experiences in learning helps children to feed knowledge to one another. These methods also promote social communication skills that children will need to possess as adults. They will need to be able to effectively discuss the various issues that will occur as life progresses. Even students with special needs can offer educational knowledge to their peers; if the students learn that they can teach others and learn from others, and then they will feel a sense of belonging, pride, and responsibility. When students are working together, these students can be paired with slower learner students from time to time. When students work together and are able to engage in discussions on different ideas, then the sky's the limit to what types of knowledge the students can transmit to one another. Peer learning helps students to build effective listening and communication skills [12].

\section{(c) Guided Learning Theory}

According to Vygotsky in Lamport, Graves and Wards [14], the zone of proximal development states that students learn when guided by an adult or when working with more capable peers. A more competent person collaborates with a child to help him move from where he is now to where he can be with help. This person accomplishes this feat by means of prompts, clues, modeling, explanation, leading questions, discussion, joint participation, encouragement, and control of the child's attention" [11]. Students with disabilities can learn from their 
peers without disabilities as well as with the support of adult guidance to gain a better understanding of the concept being taught. For example, peer tutoring has been found to be effective for students with disabilities [15]. A second example is when a teacher provides scaffolding. Scaffolding occurs when a great learning support is provided at the time new concepts are introduced and the support is slowly taken from the student as he or she masters the content. All the three theories describe how learning occurs in the classroom both academically and socially. According to Ntshangase, Mdikana and Cronk [16], high social interaction is important not only for learners' academic achievement but also for their long-term general wellbeing and personal development. The zone of proximal development, in conjunction with the social learning theory, should theoretically help explain how students with disabilities progress academically and increase appropriate social interactions with placed within an inclusion classroom [13].

\section{Prospects of Inclusive Education}

Research indicates that at the elementary school level, students with disabilities who are included in general education curricula can benefit socially and academically without facing the stigma of segregated or pull-out classrooms. Standards for behavior and instruction are higher, and students with classifications have more opportunity to reach higher standards and become independent learners [17.

Integration into the mainstream enables students with disabilities to benefit from the stimulation of mixing with relatively more able students and to have the opportunity to observe higher models of social and academic behaviour [5].

Inclusion has academic and social benefits for all students, whether with or without disabilities, such as increased communication and social interaction opportunities, age-appropriate models of behaviour skills, more active participation in the school community, individualized education goals, as well as access to the rich core curriculum [18]. Inclusion recognizes that all students are learners who benefit from a meaningful, challenging, and appropriate curriculum and differentiated instruction techniques that address their unique strengths and needs [19].

Studies also indicate that students without disabilities can benefit from inclusive settings. Findings reveal academic performance is equal or superior to comparative groups of students educated in a noninclusive setting, and students with severe disabilities do not significantly limit or interrupt instructional time for nondisabled peers in inclusive settings. Friendships and awareness of diversity are also benefits of the inclusive classroom for individuals without disabilities [3].
On an interpersonal level, inclusive education allows children to develop friendships with their peers and feel less social tension about their disabilities. Some people believe that children who are placed in standard classroom environments generally have higher self-esteem than children who are isolated to different classrooms simply because they have special needs [20].

The implementation of inclusive education system as against segregated education system has a number of advantages. These include the fact that it encourages students without disabilities to accept and tolerate children with special needs; improve the sociability of children with special needs; reduces the cost of providing separate education for children with and without special needs; eliminates or reduces social stigma associated with people with special needs; provides an all-round development of the child with and without special needs; and enables children without special needs develop positive attitude towards people with handicapping conditions [21].

\section{Challenges of Inclusive Education}

1) Expense: Funding is a major constraint to the practice of inclusion. Teaching students with disabilities in general education classrooms take specialists and additional staff to support students' need. Coordinating services and offering individual support to children requires additional money that many schools do not have, particularly in a tight economy $[22,23]$. Inadequate funding can hinder on-going professional development that keeps both specialists and classroom teachers updated on the best practices of inclusion.

2) Misinformation: One of the greatest challenges associated with inclusion in education is the negative attitude. As with society in general, this attitude and stereotype is often caused by a lack of knowledge and understanding. Public enlightenment work in schools must begin the process of educating the school and the general community in order to eradicate superstitions about causation of disabilities, and to modify the fears and myths about children with disabilities that create misunderstanding and inhibit normal interaction [24]. If educators have negative attitude towards students with special needs or have low expectations of them, children will unlikely receive a satisfactory inclusive education [25].

3) Lack of Qualified Personnel: A teacher with no basic skills in special education may not see the need to specify directions or positions when describing certain things or ideas in a class with visually impaired students. In a study carried out by Ajuwon [26] on inclusive education in Nigeria, the scholar arrived at the following findings: 'While most participants stated they were tolerant of the diverse behaviours of their students within the inclusive setting, they were less confident in 
their abilities to manage the behaviors of students with special needs. This lack of confidence in their professional competency may indicate limited training and/or exposure to inclusive practices'. Specifically, the study found that 'In terms of educational qualification, both a greater tolerance of potentially negative behaviors and a greater understanding of the needs of students with sensory disabilities were associated with higher formal training. The motivation of participants who have acquired advanced professional training may have led them to embrace new conceptualizations in the emerging field of inclusive education. This is a positive finding which underscores the necessity to provide ongoing professional development and training to special educators'. In other words, the higher the qualification of the regular teacher, the more positive attitude he/she is likely to demonstrate towards the notion of inclusion.

4) Accessibility: it is a fact that a student with disability cannot learn in an inclusive classroom if he cannot enter the classrooms, dormitories and hostels. Some schools are still inaccessible to students in wheelchairs or to those other elevators, ramps, paved pathways and lifts to get in and round buildings. Accessibility can go beyond passageways, stairs, and ramps to recreational areas, paved pathways, and door handles Fareo [22, 10].

5) Educational Modifications: Just as the environment must be accessible to students with disabilities, the curriculum must facilitate inclusive education, too. General educators must be willing to work with inclusion specialists to make modifications in classroom and homework assignments. Teachers should be flexible in how students learn and demonstrate knowledge and understanding. Written work, for example, should be limited if student cannot write and can't accomplish the same or similar learning objective through a different method.

6) Cooperation: Lack of communication among administrators, teachers, specialists, staff, parents and students inhibits the success of inclusive programme. Open communication and coordinated planning between the general education teachers and special education staff are essential for inclusion to work. Time is needed for teachers and specialists to meet and create well-constructed plans to identify and implement modification, accommodations, and specific goals for individual students. Collaboration must also exist among teacher, staff, and parents to meet a student's needs and facilitates learning at home [10].

7) Facilities and Materials: Majority of the children with special needs learn more in the environment that is full of learning resources. These learning resources are called assistive devices or assistive technological device. Evidence suggests that lack of relevant facilities and materials are major obstacle to the implementation of effective mainstreaming Fareo [22] investigated the problems of mainstreaming in Southwestern State Nigeria. The data indicated that the required educational materials were not provided, or were inadequate in regular schools where students with special needs were being mainstreamed. Further still, the data indicated lack of specialist teachers in most institutions to provide important advisory services that would assist the regular teachers managing the learners with special needs who were being mainstreamed into public schools.

\section{Implications for Counselling}

Counselling services for students with special needs is a necessary service that should be rendered by counsellors, psychologists and special teachers working with students with special needs in mainstreamed public school system. In the light of the fore going considerations, it is recommended to all school system to initiate seminars, workshops and conferences for parents of students with special needs; so that awareness could be brought about on needs of families.

The curriculum should be modified to accommodate learners with special needs different learning style so as to achieve the needed change. There is the need to get the machinery going towards the process of monitoring, in order to ensure effective implementation of inclusive schooling for children with special needs.

Teachers' should collaborate with colleagues, positive classroom management, and community building are all effective strategies that teachers can utilize within their classrooms in order to develop and maintain social inclusivity.

Counselling the public for attitudinal change would not only accommodate the students with special needs in our society, but; would also make them to be accepted as people of worth. Members of the public should be enlightened to accept, respect and show affection to students with special needs. If they have a sense of belonging, their positive self-concept and selfesteem will be enhanced.

Counsellors to appeal to Non-Governmental Organizations (NGOs)s and philanthropists to build, expand, repair and equip the existing facilities for students with special needs in order to improve inclusion.

\section{CONCLUSION}

Students with disabilities who are included in general education curricula can benefit socially and academically without facing the stigma of segregated or pull-out classrooms. However, the numerous challenges battling with inclusion such as inadequate special teachers to teach students with disabilities, lack of material and facilities, inadequate funding by the 
government to mention but few. The government, school authority, teachers, community and parents should rise to combat the problems in order to achieve the desired goals.

\section{REFERENCES}

1. Slavin, R. (2009). Educational psychology: Theory and practice (9th ed.). Upper Saddle River, New Jersey: Pearson Education, Inc.

2. UNESCO. (2006). Guidelines for inclusion: Ensuring access to education for all. Paris, UNESCO

3. Vollmer, R., \& Vollmer, J. R. (2002). Engaging students in the inclusive classroom: Research and Theoretical Underpinning Retrieved

February,10,2019 from http://www.sagepub.com/upmdata/39528_Pages_from_Green_ch1.pdf

4. Okobah, U. M. (2007). The what and how of inclusive education in the UBE? In E. D. Ozoji and J. M. Okuoyibo (Eds.), The Practice and future of special needs education in Nigeria, Jos: Dcka Nigeria.

5. Omede, A. A. (2015). Assessment of special education service delivery: A global perspective. Global Journal of Human-Social Science, Linguistics \& Education, 15(5), 1-9.

6. Kochhar, C. A., West, L. L. \& Taman, J. M. (2000). Successful inclusion, practical strategies for a shared responsibility. Upper Saddle River, N. J. Prentice Hall.

7. UNESCO. (2009). New UNESCO guidelines on inclusive education. Paris, UNESCO.

8. Federal Government of Nigeria (2014). National Policy on Education. Lagos: NERDC Press.

9. Ozoji, E.D. (2005). Special needs education and rehabilitation for beginner professionals. Jos: Deka Publications.

10. Omede, A. A. (2016). Policy framework for inclusive education in Nigeria: Issues and challenges. Public Policy and Administration Research, .6 (5), 33-38

11. Miller, P.H. (ed.). (2011). Theories of developmental psychology (5th ed.). New York: Worth Publishers.

12. Harding, S. (2009). Successful inclusion models for students with disabilities require strong site leadership: Autism and behavioral disorders create many challenges for the learning environment. International Journal of Learning, 16(3), 91-103.

13. Lamport, M. A., Graves, L \& Wards, A. (2012). Special needs students in inclusive classrooms: The impact of social interaction on educational outcomes for learners with emotional and behavioral disabilities. European Journal of Business and Social Sciences, 1(5), 54-69.
14. McDuffie, K., Mastropieri, M., \& Scruggs, T. (2009). Differential effects of peer tutoring in co taught and non-co-taught classes: Results for content learning and student-teacher interactions. Council of Exceptional Children, 75(4), 493-510.

15. Ntshangase, S., Mdikana, A., \& Cronk, C. (2008). A comparative study of self-esteem of adolescent boys with and without learning disabilities. International Journal of Special Education, 23(2), 75-84.

16. Smith, T.E.C., Polloway, E.A., Patton, J. R., \& Dowdy, C. A. (2006). Teaching students with special needs in inclusive settings (revised IDEA edition). Boston: Allyn\& Bacon,

17. Jacob, U., S \& Olisaemeka, A. N. (2016). Inclusive education in the 21 st century: parameters and opportunities for learners with special needs. European Scientific Journal, 12(10), 188-196.

18. Salend, S. J. (2005). Creating inclusive classrooms: Effective and reflective practices for all students (Sth ed.). Columbus, $\mathrm{OH}$ : Merrill/Prentice Hall

19. California Special Needs Law Group. (2009). The concept of inclusive education and understanding children with special needs. Retrieved February 8, 2019 from http://www.csnlg.com/blog/the- conceptof-inclusive-education-and-understandingchildren-with-special-needs/

20. Gesinde, M. A. (2010). Inclusive education: problems, and remedies in Theo- Ajobiewe, Adebiyi B. A and Olubela O. L. (2010). Professional standard of practice for special Educators. Retrieved February12, 2019 from http://eprints.covenantuniversity.edu.ng/

21. Fareo, D. O. (2010). Mainstreaming of students with special needs into public secondary schools in Southwestern Nigeria. Unpublished PhD thesis from Obafemi Awolowo University, Ile-Ife.

22. Stephanie, T. (2012). Barriers to inclusion in education. Retrieved February, 10, 2019 , fromww.unescobkk.org/education/appeal/program me-themes/inclusive-education/themeaticissues/barriers-to-inclusive education

23. Ajuwon, P. M. (2008). Inclusive education for students with disabilities in Nigeria: Benefits, challenges and policy implications. International Journal of Special Education, 23(3), 11-17.

24. Galadima, M. (2012). Overcoming the skeptical attitudes of regular teachers toward inclusive education approaches in Sokoto State, Nigeria. Retrieved February 9, 2019from http://www.african.org/mamuda.doc

25. Ajuwon, P. M. (2012). Making inclusive education work in Nigeria: Evaluation of special educators' attitudes. Disability Studies Quarterly, 32(2), 1-7.s. 